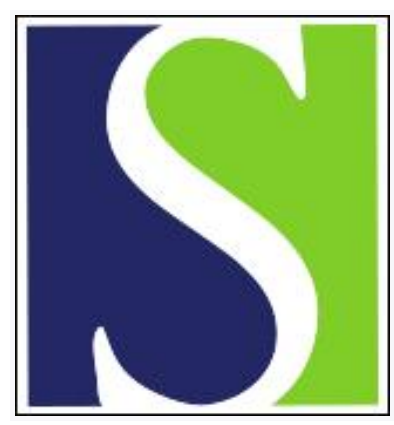

Scand J Work Environ Health 1994;20(4):286-293

https://doi.org/10.5271/sjweh.1396

Issue date: 01 Aug 1994

Cardiovascular diseases among foundry workers exposed to carbon monoxide.

by Koskela RS

Affiliation: Finnish Institute of Occupational Health, Helsinki.

This article in PubMed: www.ncbi.nlm.nih.gov/pubmed/7801074

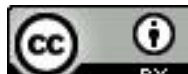




\title{
Cardiovascular diseases among foundry workers exposed to carbon monoxide
}

\author{
by Riitta-Sisko Koskela, MSocSc ${ }^{1}$
}

\begin{abstract}
KOSKELA R-S. Cardiovascular diseases among foundry workers exposed to carbon monoxide. Scand $J$ Work Environ Health 1994;20:286-93.

OBJEctives - The study investigated long-term effects of carbon monoxide (CO) exposure on foundry workers' morbidity and mortality from cardiovascular diseases.

METHODS - The study population comprised a cohort of 2857 men hired in 1950-1972 by 20 Finnish foundries and also 931 men who were still active in 1972, exposed for at least 4.2 years, took part in a health examination in 1973; 653 of the 931 had also been members of the cohort. These groups were followed to the end of 1987 .

Results - The age-standardized incidence density rate (ID/1000 person-years) for compensated medication for hypertension was 4.7 for the unexposed workers and 9.4 for those exposed [rate ratio (RR) $2.0,95 \%$ confidence interval $(95 \% \mathrm{CI}) 1.28-2.92$ ]; for the iron foundry workers the rates were 4.7 and 9.9 (RR 2.1,95\% CI 1.24-3.38), respectively. During 1950-1987, 255 cardiovascular deaths were observed ( 284 expected according to national rates). The observed number of deaths due to ischemic heart disease was 183 (203 expected). The iron foundry workers' mortality rate for cardiovascular deaths was $99 \%$ of the national expected value. No remarkable differences were found between the $\mathrm{CO}$-exposure categories. For the health-examination group, the age-standardized incidence rate for compensated medication for hypertension was 9.1 for the unexposed nonsmokers and 21.4 for the exposed smokers (RR $2.3,95 \%$ CI $0.97-6.35$ ); the difference originated among the iron foundry workers, for whom the rates were 8.1 and 24.0 (RR 3.0,95\% CI $0.96-9.78$ ), respectively. The age-standardized mortality rate (ID/1000 person-years) was 2.7 for nonsmokers with no or slight CO exposure and 9.2 for exposed smokers (95\% CI 1.13-12.11). This difference was mainly caused by ischemic heart disease.

Conclusions - The results indicate that $\mathrm{CO}$ exposure increases the risk of cardiovascular morbidity and mortality.
\end{abstract}

KEY TERMS — carbon monoxide, foundries, hypertension, ischemic disease, morbidity, mortality.

The effects of prolonged exposure to carbon monoxide (CO) on humans has been described as a complex of neurological and cardiovascular symptoms, such as angina pectoris, paroxysmal nocturnal dyspnea, chest pain, and the acceleration of coronary heart disease $(1,2)$. The association of $\mathrm{CO}$ exposure with cardiovascular diseases has been repeatedly reviewed $(3,4)$.

Evidence relating $\mathrm{CO}$ exposures to the development of systemic hypertension is not conclusive. Studies on blood pressure after $\mathrm{CO}$ exposure have shown either no change $(5,6)$ or a transient increase (7).

The pathological manifestations of $\mathrm{CO}$ exposure have been suggested to be associated with reduced oxygen delivery to the heart, the chemical effects of $\mathrm{CO}$ on myocardial cell function, the development of hypertension, or accelerated atherosclerosis and cor-

Finnish Institute of Occupational Health, Helsinki Finland.

Reprint requests to: Ms R-S Koskela, Finnish Institute of Occupational Health, Topeliuksenkatu 41 a A, FIN-00250 Helsinki, Finland onary lipid deposition due to chronic arterial hypoxia in relation to carboxyhemoglobin $(\mathrm{COHb})(4,8)$. There are controversial reports on the effect of different $\mathrm{COHb}$ levels on myocardial hypoxia in smoking and nonsmoking patients with coronary heart disease $(9,10)$.

Other toxic actions of $\mathrm{CO}$ have been proposed in addition to the production of $\mathrm{COHb}$ as a response when $\mathrm{CO}$ is inhaled. For instance, $\mathrm{CO}$ competes with oxygen for cytochrome $\mathrm{a}_{3}$ in cellular mitochondrial respiration (11-13). Extravascular $\mathrm{CO}$ is also bound to other heme proteins, such as catalase and peroxidases $(14,15)$. The predominant physiological effects of increased levels of $\mathrm{COHb}$ are still best related to reductions in the oxygen-carrying capacity of the blood (16).

The Finnish foundry study was carried out by the Finnish Institute of Occupational Health in 19721975. It comprised dust measurements, measurements of chemicals, and a study of the mortality, morbidity, and turnover of active and retired foundry workers in a representative sample from all foundries.

The retrospective cohort study of 3876 foundry men in 1973 did not reveal significant differences in 
the mortality between the $\mathrm{CO}$ categories (17). In the health examination of 931 still-active foundry workers in 1973, the systolic and diastolic blood pressures of CO-exposed workers were slightly higher than those of unexposed workers when age and smoking habits were taken into consideration (18). The prevalence of angina pectoris showed a clear dose-response relationship with regard to $\mathrm{CO}$ exposure from either occupation, smoking, or both.

The objective of the present study was to investigate long-term effects of $\mathrm{CO}$ exposure on foundry workers' morbidity and mortality from cardiovascular diseases.

\section{Subjects and methods}

\section{Subjects}

The study population comprised two groups. First there was a cohort of 2857 men hired in 1950-1972 by 20 iron, steel, and nonferrous foundries (included in the mortality study of Finnish foundry workers in 1973). This sample consisted of all men who had been employed during that period for at least five years $(N=1305)$ or for three to five years $(N=606)$ and every tenth of those exposed for three months to one year $(\mathrm{N}=946)$. The second group consisted of 931 men from a cross-sectional study. These men were still active in 1972, had been exposed for at least 4.2 years, and took part in a health examination in 1973; 653 of them had also been members of the aforementioned cohort.

The study groups were followed to the end of 1987. The vital status of the cohort members was traced through the Population Data Register. The causes of death were obtained from Statistics Finland, and data on specially compensated medication under the national sickness insurance law were acquired from the Social Insurance Institution. Data on the occupations of the men who underwent the health examination were updated from the Population Data Register. A new questionnaire study on occupational history, smoking habits, and some diseases was carried out in March 1993. The preliminary results were used to control the validity of the data on occupational and confounding exposures in this study.

\section{Exposures}

CO was measured in 1972 in 52 iron, 10 steel, and 5 copper alloy foundries. The hygienic standard for $\mathrm{CO}\left(50 \mathrm{~cm}^{3} \cdot \mathrm{m}^{-3}\right)$ was exceeded in $72 \%$ of the air samples from the iron foundries, in $9 \%$ of the samples from the steel foundries, and in $20 \%$ of the samples from the copper alloy foundries. The blood $\mathrm{COHb}$ content of the iron foundry workers exceeded $6 \%$ in $71 \%$ of the smokers and $28 \%$ of the nonsmokers (19).

On the basis of these $\mathrm{CO}$ measurements the foundry occupations were classified into the following three categories: (i) regular $\mathrm{CO}$ exposure: casters, furnacemen, and knock-out men; (ii) occasional or slight $\mathrm{CO}$ exposure: fettlers, truck drivers, crane operators, and loader drivers, and (iii) no $\mathrm{CO}$ exposure: floor molders, machine molders, coremakers, ingot casters, and other workers. In defining the main exposure category through the occupational history for the data analysis, the time-weighted average of the $\mathrm{CO}$ exposure scores (i-iii) was used.

Confounding exposure to polycyclic aromatic hydrocarbons (PAH) was controlled in an analysis of the results using PAH exposure categories. The foundry occupations were classified into these categories by an industrial hygienist, who used the measurements of PAH in the foundries in 1972.

The confounding effect of heat could not be controlled because the same occupational groups (casters and furnacemen) that were the most exposed to heat were also the most exposed to $\mathrm{CO}$.

Data on smoking habits were available for the 931 men who underwent a health examination; they were taken from the questionnaire administered in 1973. Of these foundry men, $53 \%$ were smokers, $31 \%$ were ex-smokers, and only $16 \%$ were nonsmokers (18).

\section{Statistical analysis}

In the analysis of mortality, the age-standardized incidence densities were calculated for all cardiovascular diseases and for ischemic heart disease in different exposure categories. The age distributions of the person-years for the cohort and for the healthexamined group were used as standard populations when the age-standardized rates were computed for the subgroups. The period of follow-up in the mortality analysis was from 1 January 1950 to $31 \mathrm{De}$ cember 1987 for the cohort and from 1 January 1973 to 31 December 1987 for the men who underwent a health examination. In addition, the age-specific observed and expected numbers of deaths and the standardized mortality ratios were calculated. The expected numbers of deaths were calculated from the national incidences on causes of deaths with the use of the median years of the cohort deaths (1977) (20) and the deaths of the men who underwent a health examination (1985) (21).

Morbidity from cardiovascular diseases was measured with the use of medication for which a special compensation (from 80 to $100 \%$ ) is granted according to the sickness insurance law. Hypertension, coronary heart disease, cardiac insufficiency, and cardiac arrhythmia were the cardiovascular diseases for which specially compensated medicines could be granted. The age-standardized incidences by disease were calculated in the same way as the incidence rates in the mortality analyses. Only the first grant of the compensated medication for each disease was included if the same person had several grants for certain periods. The period of follow-up for the cohort started from the beginning of the register on special medication on 1 January 1964 and ended on 31 
December 1987. The number of included grants was 503 , of which 330 were due to hypertension. For the men who underwent a health examination the incidences were calculated for the period from 1 January 1973 to 31 December 1987 (230 grants were included, 168 because of hypertension).

In the comparison of the exposure categories, both observed numbers and person-years were summarized by subgroups for the incidences needed to calculate the expected numbers for both of the categories to be tested. The deviance of the total number of observed $(\mathrm{O})$ cases from the total number expected (E) was tested by the chi-square test as follows (22):

$$
\mathrm{X}_{1}^{2}=\left[\left(\left|\mathrm{O}_{1}-\mathrm{E}_{1}\right|-0.5\right)^{2}\right] / \mathrm{E}_{1},
$$

and

$$
\mathrm{X}_{2}^{2}=\left[\left(\left|\mathrm{O}_{2}-\mathrm{E}_{2}\right|-0.5\right)^{2}\right] / \mathrm{E}_{2} .
$$

In addition, Poisson regression was used in the mortality and morbidity studies to clarify the relationship between cardiovascular diseases, $\mathrm{CO}$ exposure, and smoking (23). The statistical significance of each determinant in the model was based on likelihood ratio statistics.

\section{Results}

During the follow-up of the cohort (from 1950 to 1987) 255 cardiovascular deaths occurred, whereas

Table 1. Mortality (incidence density/1000 person-years) from all cardiovascular diseases and ischemic heart disease among the iron foundry workers by the degree of carbon monoxide (CO) exposure. The period of follow-up for the cohort was $1950-1987$

\begin{tabular}{lllllllll}
\hline & \multicolumn{3}{c}{$\begin{array}{c}\text { All cardiovascular } \\
\text { diseases }\end{array}$} & & \multicolumn{3}{c}{$\begin{array}{c}\text { Ischemic heart } \\
\text { disease }\end{array}$} \\
\cline { 2 - 3 } \cline { 7 - 9 } Co exposure & \multicolumn{3}{c}{ Years of exposure } & & \multicolumn{3}{c}{ Years of exposure } \\
& $<1$ & $3-5$ & $>5$ & & $<1$ & $3-5$ & $>5$ \\
\hline Regular & 2.3 & 2.8 & 4.1 & & 2.3 & 2.1 & 2.7 \\
Occasional & 5.5 & 3.8 & 3.9 & & 4.9 & 2.7 & 2.7 \\
No & 5.6 & 4.2 & 3.1 & & 4.5 & 4.0 & 2.4 \\
\hline Total & 5.3 & 3.6 & 3.6 & & 4.3 & 3.1 & 2.6 \\
\hline
\end{tabular}

Table 2. Age-standardized incidence densities (in units of 1000 person-years) for compensated medication for cardiovascular diseases and hypertension separately $(1964-1987)$ by exposure to carbon monoxide (CO) in the different exposure cat-

\begin{tabular}{|c|c|c|c|c|c|c|}
\hline \multirow{3}{*}{$\mathrm{CO}$ exposure } & \multirow{2}{*}{\multicolumn{3}{|c|}{$\begin{array}{c}\begin{array}{c}\text { Cardiovascular } \\
\text { diseases }\end{array} \\
\begin{array}{c}\text { Period of exposure } \\
\text { (years) }\end{array}\end{array}$}} & \multirow{2}{*}{\multicolumn{3}{|c|}{$\begin{array}{c}\text { Hypertension } \\
\begin{array}{c}\text { Period of exposure } \\
\text { (years) }\end{array}\end{array}$}} \\
\hline & & & & & & \\
\hline & $<1$ & $3-5$ & $>5$ & $<1$ & $3-5$ & $>5$ \\
\hline $\begin{array}{l}\text { Regular } \\
\text { Occasional } \\
\text { No }\end{array}$ & $\begin{array}{l}3.2 \\
8.5 \\
7.7\end{array}$ & $\begin{array}{r}14.3 \\
7.0 \\
6.2\end{array}$ & $\begin{array}{l}13.7 \\
11.4 \\
10.2\end{array}$ & $\begin{array}{l}3.2 \\
3.9 \\
4.7\end{array}$ & $\begin{array}{l}7.0 \\
3.8 \\
4.2\end{array}$ & $\begin{array}{l}9.4 \\
8.0 \\
6.3\end{array}$ \\
\hline Total & 7.5 & 7.9 & 11.4 & 4.5 & 4.7 & 7.6 \\
\hline
\end{tabular}
egories of the cohort.
283.5 were expected from the national rates. The number of deaths due to ischemic heart disease was 183 (202.8 expected). The age-standardized incidence rate per 1000 person-years of cardiovascular diseases for the workers exposed for at least five years was 3.6 for the iron foundry workers, 3.6 for the steel foundry workers, and 2.5 for the nonferrous foundries. Only small differences were found between the $\mathrm{CO}$ categories in the exposure time groups, even among the iron foundry workers (table 1). The same was true for ischemic heart disease.

On the contrary, the analysis of morbidity from cardiovascular diseases (1964-1987) revealed differences (table 2). The age-standardized incidence rate for compensated medication for hypertension was 4.7 for the workers whose exposure time was less than one year and who were not exposed to $\mathrm{CO}$ and 9.4 for those who were regularly exposed to $\mathrm{CO}$ for at least five years [rate ratio (RR) $2.0,95 \%$ confidence interval (95\% CI) 1.28-2.92]. Among the iron foundry workers the corresponding rates were 4.7 and 9.9 (RR 2.1, 95\% CI 1.24-3.38). The incidence rates for compensated medication for all cardiovascular diseases also showed statistically significant differences between the extreme exposure categories (RR 1.8, 95\% CI 1.25-2.45). Within the group of workers exposed for at least five years the rate ratio between the regularly exposed and the unexposed was 1.3 for all cardiovascular diseases (RR $1.3,95 \% \mathrm{CI} 1.01-1.82)$ and 1.5 for hypertension (RR $1.5,95 \%$ CI $1.03-2.16$ ).

In the follow-up (from 1973 to 1987) of men who underwent a health examination the age-standardized incidence rate for compensated medication for hypertension was 9.1 for the nonsmokers not exposed to $\mathrm{CO}$ and 21.4 for the CO-exposed smokers (RR 2.3, 95\% CI $0.97-6.35$ ). The difference originated among the iron foundry workers, for whom the rates were 8.1 and 24.0 (RR 3.0, 95\% CI 0.96-9.78) (figure 1). In addition, the differences between the unexposed nonsmokers and the exposed ex-smokers were statistically significant. For the iron foundry workers, the effect of $\mathrm{CO}$ only gave a rate ratio of 1.6 for the nonsmokers and 2.1 for the smokers. The effect of smoking only gave a rate ratio of 1.4 for workers not exposed to $\mathrm{CO}$ and 1.9 for the exposed workers. The combined effect of $\mathrm{CO}$ exposure and smoking showed a rate ratio of 3.0. For other cardiovascular diseases (ie, coronary heart disease, cardiac insufficiency, and cardiac arrhythmia) the age-standardized incidence was similarly lowest for the unexposed nonsmokers (2.8) and highest for the CO-exposed smokers (6.7). The age-standardized incidences for all cardiovascular diseases and hypertension separately are presented in figure 2 and table 3 .

The morbidity from hypertension was also analyzed with the use of the Poisson regression model, in which the independent variables were age, smoking, and $\mathrm{CO}$ exposure. The fit of the multiplicative 
model (age + smoking $+\mathrm{CO}$ ) was good [deviance 12.7 on 10 degrees of freedom (df)]. The corresponding additive model was inappropriate because of some negative fitted values. The interaction between smoking and $\mathrm{CO}$ exposure was nonsignificant. The coefficient of $\mathrm{CO}$ exposure was statistically significant (RR 2.3, 95\% CI 1.28-3.99), whereas that for smoking was nonsignificant (RR 1.6, 95\% CI $0.81-$

ID/1000 p-years

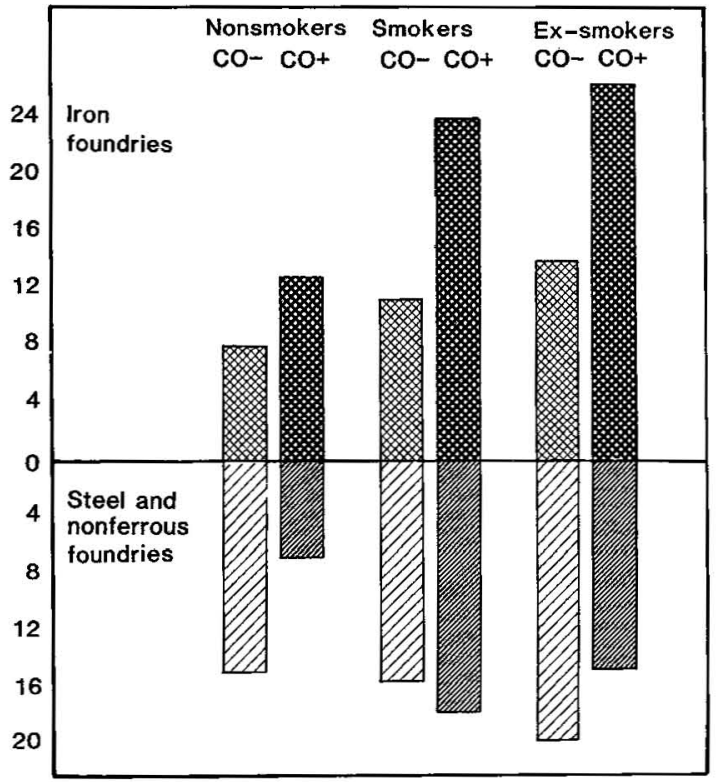

Figure 1. Age-standardized incidence densities (ID) of compensated medication for hypertension in 1973-1987 according to type of foundry, carbon monoxide (CO) exposure, and smoking habits ( $N=931$, the health-examined group). ( $p$ years $=$ person-years, $\mathrm{CO}-=$ unexposed to $\mathrm{CO}, \mathrm{CO}+=\mathrm{ex}-$ posed to $\mathrm{CO}$ )
3.13). The multiplicative model estimated the rate ratio to be 3.6 (95\% CI $1.50-8.71$ ) for CO-exposed smokers, as compared with unexposed nonsmokers.

Altogether, 140 deaths occurred in the health-examined group from 1 January 1973 to 31 December 1987; 78 of these deaths were caused by cardiovascular diseases. The age-standardized mortality rate for cardiovascular diseases was 2.7 for the nonsmok-

ID/1000 p-years

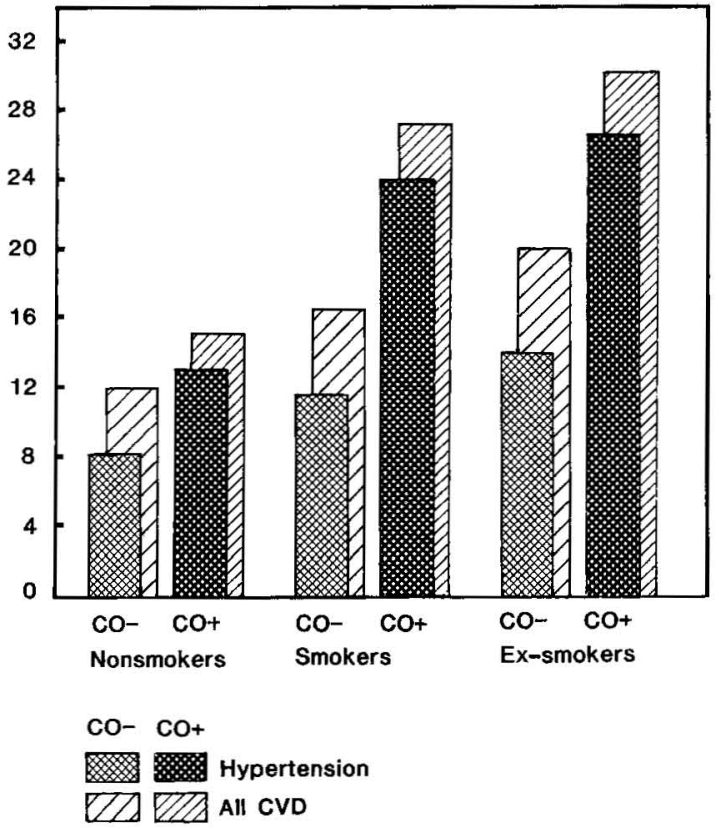

Figure 2. Age-standardized incidence densities (ID) of compensated medication for hypertension and all cardiovascular diseases (all CVD) in 1973-1987 according to carbon monoxide (CO) exposure and smoking habits among the iron foundry workers ( $N=458$, the health-examined group). ( $p$ years $=$ person-years, $\mathrm{CO}-=$ unexposed to $\mathrm{CO}, \mathrm{CO}+=\mathrm{ex}$ posed to $\mathrm{CO}$ )

Table 3. Relation of carbon monoxide $(\mathrm{CO})$ exposure and smoking to morbidity from all cardiovascular diseases and from hypertension among the iron foundry workers in 1973-1987. (Smoking $-=$ nonsmokers, smoking $+=$ smokers, CO exposure $-=$ no or slight exposure to $\mathrm{CO}, \mathrm{CO}$ exposure $+=$ exposed to $\mathrm{CO}, \mathrm{NS}=$ not significant)

\begin{tabular}{|c|c|c|c|c|c|c|c|}
\hline \multirow{2}{*}{ Studied variables } & & \multicolumn{3}{|c|}{ All cardiovascular diseases } & \multicolumn{3}{|c|}{ Hypertension } \\
\hline & & $\begin{array}{l}\text { Rate } \\
\text { ratio }\end{array}$ & $x_{(1)^{2}}$ & $\begin{array}{l}\text { Signifi- } \\
\text { cance }\end{array}$ & $\begin{array}{l}\text { Rate } \\
\text { ratio }\end{array}$ & $X_{(1)^{2}}$ & $\begin{array}{l}\text { Signifi- } \\
\text { cance }\end{array}$ \\
\hline \multicolumn{8}{|l|}{ CO exposure only } \\
\hline Smoking - & $\begin{array}{l}\text { CO exposure- } \\
\text { CO exposure + }\end{array}$ & 1.3 & 0.21 & NS & 1.6 & 0.69 & NS \\
\hline Smoking + & $\begin{array}{l}\text { CO exposure - } \\
\text { CO exposure + }\end{array}$ & 1.8 & 3.52 & NS & 2.1 & 5.06 & $<0.025$ \\
\hline \multicolumn{8}{|l|}{ Smoking only } \\
\hline CO exposure- & $\begin{array}{l}\text { Smoking - } \\
\text { Smoking + }\end{array}$ & 1.4 & 0.49 & NS & 1.4 & 0.38 & NS \\
\hline $\mathrm{CO}$ exposure + & $\begin{array}{l}\text { Smoking- } \\
\text { Smoking + }\end{array}$ & 1.9 & 2.14 & NS & 1.9 & 1.85 & NS \\
\hline \multicolumn{8}{|c|}{ CO exposure and smoking } \\
\hline $\begin{array}{l}\text { CO exposure- } \\
\text { CO exposure + }\end{array}$ & $\begin{array}{l}\text { Smoking - } \\
\text { Smoking + }\end{array}$ & 2.4 & 4.46 & $<0.05$ & 3.0 & 4.27 & $<0.05$ \\
\hline
\end{tabular}


ers slightly or not exposed to $\mathrm{CO}$ and 9.2 for the smokers with $\mathrm{CO}$ exposure (RR 3.4, 95\% CI 1.1312.11). This difference was caused by ischemic heart diseases, for which the corresponding rates were 1.0 and 7.3 (RR 7.3, 95\% CI 1.39-60.96) (figure 3 and table 4).

Mortality from ischemic heart disease was also analyzed by the Poisson regression model. The independent variables were age, smoking, and $\mathrm{CO}$ exposure. The fit of the multiplicative model (age + smoking $+\mathrm{CO}$ ) was good (deviance 10.1 on $10 \mathrm{df}$ ).

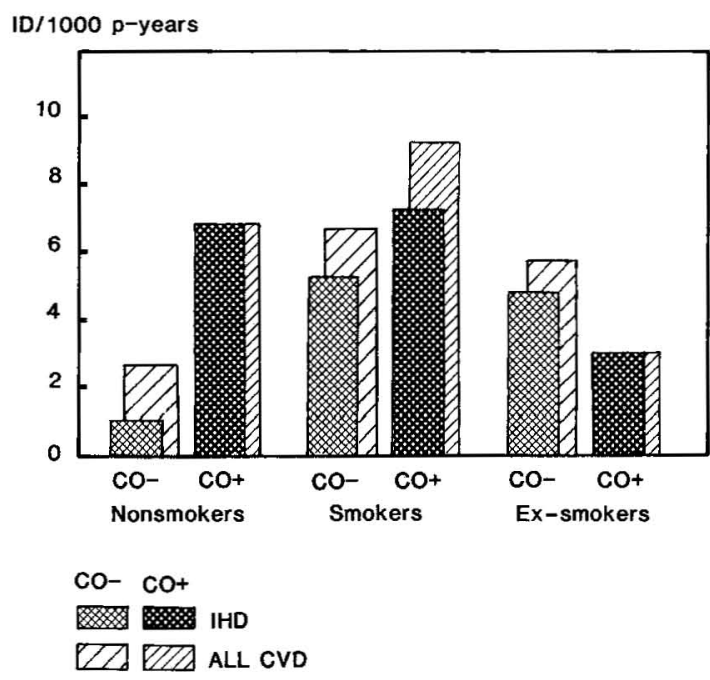

Figure 3. Age-standardized mortality from ischemic heart disease (IHD) and from all cardiovascular diseases (ALL CVD) (cardiovascular diseases) according to CO exposure and smoking habits. The period of follow-up was 1973-1987 ( $N=931$, the health-examined group). (ID = incidence density, $\mathrm{p}$-years $=$ person-years, $\mathrm{CO}-=$ unexposed to $\mathrm{CO}, \mathrm{CO}+$ $=$ exposed to $\mathrm{CO}$ )
In this case the corresponding additive model was also inappropriate. The interaction between smoking and $\mathrm{CO}$ exposure was nonsignificant. Smoking was statistically significant (RR 3.0, 95\% CI 1.05-8.36). The coefficient of $\mathrm{CO}$ exposure was not statistically significant, but it was slightly related to mortality from ischemic heart disease (RR $1.5,95 \% \mathrm{CI}$ $0.75-2.90$ ). The multiplicative model estimated the rate ratio as being 4.4 (95\% CI $1.27-15.08)$ for the $\mathrm{CO}$-exposed smokers, as compared with the unexposed nonsmokers.

The analysis of mortality from ischemic heart disease among the workers with mild or severe angina pectoris in 1973 showed the highest incidence rate for $\mathrm{CO}$-exposed smokers. (However, the analysis was based on only 62 deaths.)

A detailed analysis of the 62 deaths from ischemic heart disease showed that 38 originated in the iron foundries, 21 in the steel foundries, and 3 in the nonferrous foundries. The median exposure time for the workers who died from ischemic heart disease was 25 (range 5-48) years, whereas it was 21 (range 449) years for those who died from the other causes.

Of the 62 workers who died from ischemic heart disease, 28 died during foundry employment, 8 died within two years after the cessation of foundry work, and 16 of the remaining 26 had some heart disease diagnosed during their employment.

\section{Discussion}

In estimating the validity of the results, the mortality and morbidity of the health-examined group was reanalyzed using the updated occupational histories (until 1985), derived from the population data register and the national pension register. Both the mortality and morbidity figures remained similar. The register-based (updated as of December 1985) occu-

Table 4. Relation of carbon monoxide $(\mathrm{CO})$ exposure and smoking to mortality from all cardiovascular diseases and from ischemic heart disease among the foundry workers in 1973-1987. (Smoking $-=$ nonsmokers, smoking $+=$ smokers, CO exposure $-=$ no or slight exposure to $\mathrm{CO}, \mathrm{CO}$ exposure $+=$ exposed to $\mathrm{CO}, \mathrm{NS}=$ not significant)

\begin{tabular}{|c|c|c|c|c|c|c|c|}
\hline \multirow[b]{2}{*}{ Studied variables } & & \multicolumn{3}{|c|}{ All cardiovascular diseases } & \multicolumn{3}{|c|}{ Ischemic heart disease } \\
\hline & & $\begin{array}{l}\text { Rate } \\
\text { ratio }\end{array}$ & $X_{(1)^{2}}{ }^{2}$ & $\begin{array}{l}\text { Signifi- } \\
\text { cance }\end{array}$ & $\begin{array}{l}\text { Rate } \\
\text { ratio }\end{array}$ & $X_{(1)^{2}}{ }^{2}$ & $\begin{array}{l}\text { Signifi- } \\
\text { cance }\end{array}$ \\
\hline \multicolumn{8}{|l|}{ CO exposure only } \\
\hline Smoking- & $\begin{array}{l}\text { CO exposure - } \\
\text { CO exposure + }\end{array}$ & 2.6 & 1.36 & NS & 6.9 & 4.64 & $<0.05$ \\
\hline Smoking + & $\begin{array}{l}\text { CO exposure - } \\
\text { CO exposure + }\end{array}$ & 1.4 & 0.35 & NS & 1.4 & 0.33 & NS \\
\hline \multicolumn{8}{|l|}{ Smoking only } \\
\hline CO exposure- & $\begin{array}{l}\text { Smoking - } \\
\text { Smoking + }\end{array}$ & 2.5 & 3.33 & NS & 5.2 & 4.77 & $<0.05$ \\
\hline CO exposure + & $\begin{array}{l}\text { Smoking- } \\
\text { Smoking + }\end{array}$ & 1.3 & 0.10 & NS & 1.1 & 0.00 & NS \\
\hline \multicolumn{8}{|c|}{ CO exposure and smoking } \\
\hline $\begin{array}{l}\text { CO exposure - } \\
\text { CO exposure + }\end{array}$ & $\begin{array}{l}\text { Smoking - } \\
\text { Smoking + }\end{array}$ & 3.4 & 6.04 & $<0.025$ & 7.3 & 7.76 & $<0.025$ \\
\hline
\end{tabular}


pational histories were also controlled through the recent questionnaire from March 1993. The exposure time on the questionnaire was the same, \pm 2 years, as that recorded from the registers for $82 \%$ of the workers.

The confounding effect of smoking could be controlled only for the men who underwent a health examination. The smoking habits were classified according to the questionnaire data from 1973. A comparison of the data on smoking habits from March 1993 with those from 1973 revealed that $73 \%$ of the respondents had the same smoking category (nonsmoker, smoker, or ex-smoker) through the 20 years, and, if the categories of smokers and ex-smokers were combined, the value rose to $93 \%$.

During the investigation the $\mathrm{CO}$ concentration in the foundry air was lowered. The measurements showed that in 1972-1975 the mean CO concentration was $94 \mathrm{mg} \cdot \mathrm{m}^{-3}$ in the smelting and casting areas, whereas in 1986-1989 the mean was $41 \mathrm{mg} \cdot \mathrm{m}^{-3}$ in the same areas (24). However, the study populations were mainly exposed to the higher $\mathrm{CO}$ concentrations used in the exposure classification in the data analysis. Of the whole cohort, $40 \%$ had started their work before the 1960 s and $75 \%$ before the end of 1965 . For the men who underwent a health examination the median year of entry was 1960 . Of the total of 931 men, $38 \%$ had already terminated work by 1980 , and $63 \%$ by 1985 , and of the 270 men who continued working after 1985, 78\% had started foundry work before the end of 1965 .

In controlling for potential confounders other than smoking, the age-standardized incidences of compensated medication were calculated for hypertension also according to the PAH exposure categories (25, 26) (table 5). The results did not show any dose-response relationship with regard to exposure to $\mathrm{PAH}$, even though smoking was taken into consideration. Less than $25 \%$ of the men exposed to $\mathrm{PAH}$ were also exposed to $\mathrm{CO}$.

It was not possible to eliminate the confounding effect of heat because the same occupational groups were exposed to both $\mathrm{CO}$ and heat and the outcome diseases are at least partly the same. Tachycardia is mentioned as an effect of several months in a hot job. Hypertension and myocardial damage have been reported to be the result of many years in a hot job $(27,28)$.

Heart rate and blood pressure are the major determinants of myocardial oxygen consumption, and the adverse health effects of $\mathrm{CO}$ are thought to be related primarily to the development of tissue hypoxia. Particularly patients with atherosclerotic coronary artery disease are potentially at increased risk of adverse effects because of their limited ability to increase coronary blood flow in response to increased myocardial oxygen demand (29).

The previous cohort study in $1973(17,30)$, as well as the present follow-up of the cohort, did not show any notable differences in mortality from all car-
Table 5. Age-standardized incidence densities (in units of 1000 person-years) for compensated medication for hypertension (1973-1987) by exposure to polycyclic aromatic hydrocarbons $(\mathrm{PAH})$ and smoking habits in the group that underwent a health examination.

\begin{tabular}{lcccc}
\hline & \multicolumn{4}{c}{ Incidence density } \\
\cline { 2 - 5 } PAH & $\begin{array}{c}\text { Non- } \\
\text { exposure }\end{array}$ & Smokers & $\begin{array}{c}\text { Ex- } \\
\text { smokers }\end{array}$ & Total \\
\hline Heavy & 6.1 & 11.5 & 18.6 & 12.9 \\
Some & 14.0 & 7.2 & 13.8 & 11.1 \\
Low & 12.1 & 19.0 & 20.0 & 18.0 \\
Miscellaneous & 7.0 & 18.0 & 15.3 & 15.3 \\
\hline
\end{tabular}

diovascular diseases or that from ischemic heart disease between the $\mathrm{CO}$-exposure categories. The present prospective follow-up of the cardiovascular mortality of the foundry workers who took part in the health examination in 1973 suggested that both occupational $\mathrm{CO}$ exposure and smoking independently increased mortality from ischemic heart disease, and the combined increase was multiplicative. Similar results have been reported by several authors (31-34). The inconsistency of the results derived from the cohort and the men who underwent a health examination can be explained mainly by exposure histories and smoking histories that were lacking in the cohort study, as well as by health selection. Also in the health-examined group, the differences between the CO-exposure categories would have been small if the data on smoking had not been available. (The age-standardized mortality rate for all cardiovascular diseases was 6.3 for the workers exposed to $\mathrm{CO}$ and 5.7 for those who were slightly or not exposed to $\mathrm{CO}$; the corresponding rates for ischemic heart disease were 5.5. and 4.5.) In addition, the exposure time in foundry work was long for the men who underwent a health examination. The minimum exposure time in 1973 was 4.2 years, and the median was 25 years at the end of 1987. These results are thus comparable only with those obtained from the cohort study for the subgroup with at least five years of exposure. Health selection findings in regard to heart diseases had an important explanatory value in the earlier phase of the cohort study (30). Angina pectoris or severe chest pain lasting half an hour or more or heart disorders were more prevalent among former than among current employees, the prevalences being highest for ex-foundrymen who had been exposed for less than one year.

In 1973 the prevalence of angina pectoris showed a clear dose-response relationship with regard to occupational $\mathrm{CO}$ exposure and smoking. The highest mortality rate for ischemic heart disease was observed among the workers who had mild or severe angina pectoris in 1973 and who were CO-exposed smokers. The effect of even low increases in $\mathrm{COHb}$ in the smokers with ischemic heart disease has to be considered because $\mathrm{COHb}$ levels in smokers are generally higher than in nonsmokers $(19,35)$. 
The risk for cardiovascular disease is generally assumed to increase steadily as blood pressure increases. However, evidence relating $\mathrm{CO}$ exposures to the development of systemic hypertension is not conclusive $(5,6,7)$.

Slightly higher blood pressure was found in 1973 among the workers exposed to $\mathrm{CO}$ when smoking was taken into consideration. The present follow-up of compensated medication for hypertension showed higher incidences for the workers regularly exposed to $\mathrm{CO}$ than for those with no or slight exposure both in the cohort and in the group of men who underwent a health examination. The dose-response according to $\mathrm{CO}$ exposure and smoking was more evident among the iron foundry workers than among the steel and nonferrous foundry workers (figure 1). The result suggests that the difference between the "CO exposure categories" cannot be explained by the confounding effect of heat stress, even though the heat would have augmented the total risk of hypertension in the categories. This finding is in concordance with the findings in 1972 , namely, that the CO concentrations were the highest in the iron foundries around the cupolas and in the casting areas. Similarly the $\mathrm{COHb}$ levels of the iron foundry workers were high and showed an additional effect from smoking (19).

Furthermore, the follow-up of the health-examined group showed that the period between the diagnosis of hypertension and death from ischemic heart disease was rather short (median 7 years, range $2-16$ years). Thus it is unlikely that hypertension alone would have increased the risk of mortality from ischemic heart disease.

There is considerable uncertainty about the role of $\mathrm{CO}$ exposure in the development of atherosclerosis $(4,36)$. Although there are few empirical and epidemiologic studies supporting the hypothesis on the $\mathrm{CO}$-atherosclerosis relationship, it has been shown that the development of atherosclerosis and coronary lipid deposition can be enhanced by arterial hypoxia $(37,38)$. Tissue oxygen insufficiency caused by long-lasting exposure to $\mathrm{CO}$ could be one pathogenic factor in the development of atheromatosis. On these grounds, the present prospective results support the hypothesis of a relation between chronic $\mathrm{CO}$ exposure and the development of atherosclerosis.

\section{Acknowledgments}

I wish to express my sincerest thanks to Professor M Klockars for his advice on the medical questions, to $\mathrm{E}$ Järvinen, MSc, for his statistical advice, to $\mathrm{P}$ Mutanen, MSc, for the multivariate analyses, and to A Tossavainen, DTech, for his help with the classification of exposures. I also wish to thank Ms R Lukinmaa for collecting the data and coding the occupational histories and S Simonen, BSc, and J-A Sorsa, BSc, for the data processing. I also thank the
Social Insurance Institution for the data on specially compensated medication, Statistics Finland for the data on causes of death, and the Population Register Center for data on vital statuses and addresses.

\section{References}

1. Goldsmith JR, Landaw SA. Carbon monoxide and human health. Science 1968;162:1352-9.

2. Goldsmith JR. Carbon monoxide research - recent and remote. Arch Environ Health 1970;21:118-20.

3. Zenz $C$. The epidemiology of carbon monoxide in cardiovascular disease in industrial environments: a review. Prev Med 1979;8:279-88.

4. Kristensen TS. Cardiovascular diseases and the work environment: a critical review of the epidemiologic literature on chemical factors. Scand J Work Environ Health 1989; 15:245-64.

5. Adams JD, Erickson H, Stone HL. Myocardial metabolism during exposure to carbon monoxide in the conscious dog. J Appl Physiol 1973;34:238-42.

6. Stewart RD, Fisher TN, Baretta ED, Herrmann AA. Scientific communications: experimental human exposure to high concentrations of carbon monoxide. Arch Environ Health 1973;26:1-7.

7. Ayres SM, Giannelli S Jr, Muller H. Myocardial and systemic responses to carboxyhemoglobin. Ann NY Acad Sci 1970;174:268-93.

8. Rylander R, Vesterlund J. Carbon monoxide criteria: with reference to effects on the heart, central nervous system and fetus. Scand J Work Environ Health 1981;7 suppl 1:39p.

9. Sheps DS, Kirkwood FA, Bromberg PA, Goldstein GM, O'Neil JJ, Horstman D, et al. Lack of effect of low levels of carboxyhemoglobin on cardiovascular function in patients with ischemic heart disease. Arch Environ Health 1987;42:108-16.

10. Allred EN, Bleecker ER, Chaitman BR, Dahms TE, Gottlieb SO, Hackney JD, et al. Short-term effects of carbon monoxide exposure on the exercise performance of subjects with coronary artery disease. $\mathrm{N}$ Engl J Med 1989;321:1426-32.

11. Goldbaum LR, Orellano T, Dergal E. Mechanism of the toxic action of carbon monoxide. Ann Clin Lab Sci 1976;6:372-6.

12. Goldbaum TS, Goldbaum LR. Carbon monoxide and myocardial ischemia [editorial]. N Engl J Med 1990; 322:1086-7.

13. Dennis RC, Valeri CR. Measuring percent oxygen saturation of hemoglobin, percent carboxyhemoglobin and methemoglobin and concentrations of total hemoglobin and oxygen in blood of man, dog and baboon. Clin Chem 1980;26:1304-8.

14. Coburn RF. The carbon monoxide body stores. Ann NY Acad Sci 1970;174:11-22.

15. Coburn RF. Biological effects of carbon monoxide: summary. Ann NY Acad Sci 1970; 174:429-30.

16. Dwyer EM, Turino GM. Carbon monoxide and cardiovascular disease. N Engl J Med 1989;321:1474—5.

17. Koskela R-S, Hernberg S, Kärävä R, Järvinen E, Nurminen M. A mortality study of foundry workers. Scand J Work Environ Health 1976;2 suppl 1:73-89.

18. Hernberg S, Kärävä R, Koskela R-S, Luoma K. Angina pectoris, ECG findings and blood pressure of foundry workers in relation to carbon monoxide exposure. Scand J Work Environ Health 1976;2 suppl 1: 54-63.

19. Virtamo M, Tossavainen A. Carbon monoxide in foundry air. Scand J Work Environ Health 1976;2 suppl $1: 37-41$.

20. World Health Organization (WHO). World health sta- 
tistics annual 1977: vital statistics and causes of death. Geneva: WHO, 1981.

21. World Health Organization (WHO). World health statistics annual 1985: vital statistics and causes of death. Geneva: WHO, 1987.

22. Rothman KJ, Boice JD Jr. Epidemiologic analysis with a programmable calculator. Boston, MA: Epidemiology Resources, Inc, 1982.

23. Breslow NE, Day NE, Heseltine E. Statistical methods in cancer research: the design and analysis of cohort studies; vol II. Lyon: International Agency for Research on Cancer, 1987. IARC scientific publications, no 82.

24. Occupational health and work environment in Finland. Helsinki: Institute of Occupational Health, 1992:251p. Committee report 1991:43; reviews 119.

25. Schimberg RW, Pfäffli P, Tossavainen A. Profilanalyse von polycyclischen aromatischen Kohlenwasserstoffen in Eisengiessereien. Staub 1978;38:273-6.

26. Tossavainen A, Pfäffli P, Schimberg R, Raunio V, Pääkkönen R, Ölander RM. Identification, quantitation and mutagenicity testing of polynuclear aromatic hydrocarbons in foundry air. In: Pleština R, editor. XIX International Congress on Occupational Health, Dubrovnik, Yugoslavia, Sept 25-30, 1978, Abstracts. Zagreb: Institute for Medical Research and Occupational Health, 1978:467.

27. Dukes-Dobos FN. Hazards of heat exposure: a review. Scand J Work Environ Health 1981;7:73-83.

28. Kristensen TS. Cardiovascular diseases and the work environment: a critical review of the epidemiologic literature on nonchemical factors. Scand J Work Environ Health $1989 ; 15: 165-79$.

29. Allred EN, Bleecker ER, Chaitman BR, Dahms TE, Gottlieb SO, Hackney JD, et al. Short-term effects of carbon monoxide exposure on the exercise perform- ance of subjects with coronary artery disease. $\mathrm{N}$ Engl J Med 1989;321:1426-32.

30. Koskela R-S, Luoma K, Hernberg S. Turnover and health selection among foundry workers. Scand J Work Environ Health 1976;2 suppl 1:90-105.

31. Buchwald $H$. Exposure of garage and service station operatives to carbon monoxide: a survey based on carboxyhemoglobin levels. Am Ind Hyg Assoc J 1969;30:570-5.

32. Jones RD, Commins BT, Cernik AA. Blood lead and carboxyhemoglobin levels in London taxi drivers. Lancet 1972;2:302-3.

33. Ayres SM, Evans R, Licht D, Griesbach J, Reimold F, Ferrand EF, et al. Health effects of exposure to high concentrations of automotive emissions: studies in bridge and tunnel workers in New York City. Arch Environ Health 1973;27:68-78.

34. Stern FB, Lemen RA, Curtis RA. Exposure of motor vehicle examiners to carbon monoxide: a historical prospective mortality study. Arch Environ Health 1981;36:59-66.

35. Astrup P, Kjeldsen K. Carbon monoxide, smoking and atherosclerosis. Med Clin North Am 1974;58:323-50.

36. Weir FW, Fabiano VL. Re-evaluation of the role of carbon monoxide in production or aggravation of cardiovascular disease processes. J Occup Med 1982;24:519-25.

37. Lorenzen I, Helin P. Arteriosclerosis induced by hypoxia. Acta Pathol Microbiol Immunol Scand 1967; 69:158-9.

38. Myasnikov AL. Influence of some factors on development of experimental cholesterol atherosclerosis. Circulation 1958;17:99-113.

Received for publication: 23 June 1993 